УДК 338.24:640.41

DOI https://doi.org/10.32851/2708-0366/2020.4.6

Незвещук-Когут T.C.

кандидат економічних наук, доцент, доцент кафедри технології та організації готельно-ресторанного бізнесу,

Чернівецький торговельно-економічний інститут

Київського національного торговельно-економічного університету

Язіна В.A.

кандидат економічних наук,

доцент кафедри готельно-ресторанної справи та товарознавства, Університет митної справи та фрінансів

Nezveshchuk-Kohut Tetiana

Chernivtsi Trade and Economics Institute of

Kyiv National University of Trade and Economics

Yazina Viktoriia

University of Customs and Finance

\title{
ГОТЕЛЬНО-РЕСТОРАННЕ ГОСПОДАРСТВО ЯК ОСНОВНА СКЛАДОВА ЧАСТИНА СФЕРИ ТУРИЗМУ ТА ÏI ВПЛИВ НА СОЦІАЛЬНО-ЕКОНОМІЧНИЙ РОЗВИТОК УКРАЇНИ
}

\section{HOTEL AND RESTAURANT AS A MAIN COMPONENT OF TOURISM AND ITS IMPACT ON THE SOCIO-ECONOMIC DEVELOPMENT OF UKRAINE}

Стаття присвячена засадам функиіонування та розвитку готельно-ресторанного господарства, шьо є основною складовою частиною сфери туризму. Розглянуто актуальність створення ефективної системи регулювання готельно-ресторанним господарством у туризмі та обтрунтовано необхідніст застосування багатоелементної системи функиіонування туристичної індустрії України. Готельно-ресторанне господарство розглянуто як один з пріоритетних напрямів розвитку туристичного господарства, щцо здійснює вагомий вплив на сочіально-економічний розвиток Украӥни. Визначено основні складові частини управління туристичною індустрією. Особливу увагу приділено визначенню елементів туристичної індустрії, які створюють комплексну систему управління туристичним господарством як важливим сектором економіки, щзо відіграє важливу роль у соціально-економічному розвитку України. Наведено деякі заходи індустрії туризму щодо підвищення рівня сучасного економічного розвитку країни в умовах поширення пандеміï Covid-19.

Ключові слова: готельно-ресторанне господарство, індустрія туризму, сочіальноекономічний розвиток, туристична політика.

Статья посвящуена основам функционирования и развития гостинично-ресторанного хозяйства, которое является основной составляющей сферы туризма. Рассмотрена актуальность создания эффективной системы регулирования гостинично-ресторанным хозяйством в туризме и обоснована необходимость применения многоэлементной системы функционирования туристической индустрии Украины. Гостинично-ресторанное хозяйство рассмотрено как одно из приоритетных направлений развития туристического хозяйства, которое осуществляет значительное влияние на сочиально-экономическое развитие Украиныл. Определены основные составляющие управления туристической индустрией. Особое внимание уделено определению элементов туристической индустрии, которые создают комплексную систему управления туристическим хозяйством как важным сектором экономики, которое играет важную роль в социильно-экономическом развитии Украиныл. Приведены некоторые меры индустрии туризма по повыцению уровня современного экономического развития страны в условиях распространения Covid-19.

Ключевые слова: гостинично-ресторанное хозяйство, индустрия туризма, сочиальноэкономическое развитие, туристическая политика. 
The article is devoted to the principles of operation and development of the hotel and restaurant industry, which is highlighted as a major factor in the tourism industry. The hospitality industry is a special independent branch of the economy, consisting of a group of industries and enterprises whose functions are to meet the diverse demand for various types of recreation and entertainment. The main determinants of hospitality industry development today are the hotel and restaurant industry. Tourism is considered to be an economic category because it promotes the production and implementation of a wide range of services, job creation, income generation, infrastructure development and diversification of the country's economy. The urgency of creating an effective system of regulation of the hotel and restaurant industry in tourism is considered and the necessity of applying a multielement system of functioning of the tourist industry of Ukraine is substantiated. Important is the role of the hotel and restaurant business in fulfilling many social and economic functions. The hotel and restaurant industry is considered as one of the priority areas for the development of the tourism industry, which has a significant impact on the socio-economic development of Ukraine. The main components in the management of the tourism industry are identified. Particular attention is paid to identifying elements of the tourism industry that create a comprehensive tourism management system as an important sector of the economy, which plays an important role in the socio-economic development of Ukraine. Global trends in international tourism make it possible to attribute the tourism business to the most promising sectors of the economy, which includes a large number of elements, including the hotel and restaurant industry. Some measures in the tourism industry to increase the level of socio-economic development of the country are outlined. The market model of the Ukrainian economy necessitates the improvement of the mechanism of tourism development, in particular the hotel and restaurant industry, which is connected with the intensification of this industry, increasing competition in the world market. Recommendations are given for improving the level of development of the hotel and restaurant business in the country in the context of the spread of Covid-19.

Key words: hotel and restaurant industry, socio-economic development, tourism industry, tourism policy.

Постановка проблеми. Сфера туризму відіграє одну з провідних ролей в економічній системі багатьох розвинених країн. Ефективне функціонування економіки, iii збалансованість і пропорційність та розвиток продуктивних сил у багатьох країн світу майже неможливі без належного розвитку туристичної індустрії. Сьогодні сфера туризму включає безліч компонентів та складових частин, однак одним з основних $€$ готельно-ресторанне господарство, яке здійснює вагомий вплив на соціально-економічний розвиток будь-якої країни. Чим активніше відбуваються процеси розвитку готельно-ресторанного господарства як важливої складової частини туризму, тим швидше темпи функціонування та розвитку соціальних та економічних явищ і процесів. Однак варто зазначити, що готельно-ресторанне господарство - це сфера, що легко піддається впливу зовнішніх факторів, таких як курси валют, різноманітні катаклізми, банкрутство світових лідерів туроперейтингу (наприклад, Thomas Cook y 2019 році), політична та економічна ситуації у світі, різноманітні тренди на послуги гостинності, постійні зміни поведінки споживачів послуг гостинності. До названих негативних факторів зовнішнього впливу сьогодні можна додати світову пандемію Covid-19, що надав усій сфері гостинності нищівного удару протягом усього 2020 року.

Зазначене загострило актуальність дослідження проблеми негативних явищ у сфері гостинності, спричинених карантинними заходами, та розроблення можливих рекомендацій щодо відновлення роботи підприємств готельно-ресторанного господарства як важливого чинника соціально-економічного розвитку країни.

В умовах високої конкуренції і прагнення підприємств готельно-ресторанного господарства до економічного розвитку аналіз їх впливу на соціально-економічний стан країни набуває все більшого значення. Цей фактор нині стає найбільш значущим, як показує практика функціонування міжнародного туристичного ринку. В Укра- 
їні вже усвідомлено, що туризм - це важливий сектор економіки, існує необхідність вивчення того, як саме впливають його компоненти на соціально-економічний розвиток. Водночас зросла увага науковців до проблем розвитку туризму та його основних складових частин.

Аналіз останніх досліджень і публікацій. Роль туризму, зокрема готельно-ресторанного господарства, у світовій економіці, основні проблеми, умови та чинники їх розвитку розглядаються багатьма вітчизняними та зарубіжними вченими. Сучасний стан і тенденції розвитку готельно-ресторанного господарства дістали відображення у працях науковців, таких як А.В. Бакурова, С.М. Васильченко, Н.В. Валінкевич, Н.І. Данько [3], А.В. Діденко, Н.М. Гоблик-Маркович, Л.О. Іванова, Ю.Б. Миронов [6], Є.С. Милинчук, Л.І. Нечаюк, Н.О. Телеш, В.К. Федорченко [8], А.Д. Чудновський. Незважаючи на значний інтерес до дослідження розвитку готельно-ресторанного господарства, багато аспектів його функціонування потребують додаткової уваги, зокрема його організаційний механізм. Внесок готельно-ресторанного господарства у соціально-економічний розвиток, його значення для світової економіки, зокрема 3 урахуванням сучасних світових тенденцій, останнім часом швидко зростає, що обумовило актуальність теми дослідження.

Формулювання цілей статті. Метою статті є визначення сучасного стану розвитку готельно-ресторанного господарства; розгляд та аналіз основних економічних показників, що впливають на діяльність готельно-ресторанного господарства; визначення впливу карантинних заходів, спричинених світовою пандемією, на розвиток підприємств сфери гостинності; надання рекомендацій щодо відновлення їх роботи у посткарантинний період.

Виклад основного матеріалу. В останні десятиріччя туризм посідав провідне місце в економіці багатьох країн світу. Його роль як багатокомпонентної галузі, що включає надання специфічних та супутніх послуг та продаж товарів, важко переоцінити. Незважаючи на велику кількість складових частин, що формують туристичний продукт, основною і головною невід'ємною його складовою частиною є готельно-ресторанне господарство [7].

Готельно-ресторанне господарство - це один з видів економічної діяльності, що, окрім великих готельних ланцюгів, належить до малого та середнього підприємництва, котрий безпосередньо або опосередковано створює нові робочі місця й стає важливим засобом поповнення бюджету різних рівнів [5].

Особливістю діяльності готельно-ресторанного господарства $є$ надання послуг щодо тимчасового розміщення та реалізації продукції у закладах ресторанного господарства, що поєднує як нематеріальний характер (готельні послуги), так і матеріальний характер (приготовлена страва (готова продукція) та напій (готова продукція чи товар)). Саме тому сфера гостинності піддається впливу зовнішніх факторів як на рівні держави, так і на рівні індивідуального споживача 3 його особливими смаками та вподобаннями.

Загалом сферу готельно-ресторанного господарства можна представити як сукупність типів наявних закладів розміщення та ресторанного господарства (табл. 1).

Аналізуючи сферу гостинності за представленою таблицею, зазначаємо, що сфера гостинності в Україні представлена широким спектром закладів розміщення і закладів ресторанного господарства та має чималий відсоток у загальній структурі національної економіки.

Так, за даними Державного комітету статистики України, у 2019 році кількість колективних засобів розміщення складала 5335 суб'єктів підприємництва; загальні кількість місць номерного фонду складала 370,6 тис.; кількість осіб, що перебували у колективних засобах розміщення, складала 6 960,9 тис. осіб, з них 959,4 тис. іноземних громадян. 
Типова структура типів закладів сфери гостинності

Таблиця 1

\begin{tabular}{|c|c|c|c|}
\hline \multicolumn{2}{|r|}{ Засоби розміщення } & \multicolumn{2}{|c|}{ Заклади ресторанного господарства } \\
\hline \multirow{9}{*}{ 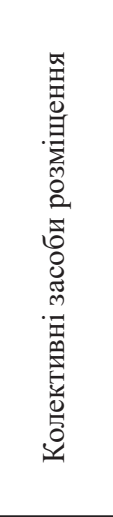 } & \multirow{2}{*}{ Готелі й аналогічні засоби розміщення } & \multirow{9}{*}{ 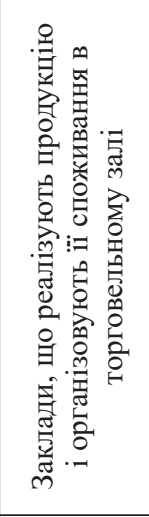 } & Ресторан \\
\hline & & & Бар \\
\hline & \multirow{4}{*}{$\begin{array}{l}\text { Готелі (готелі, готелі квартирного } \\
\text { типу, мотелі, дорожні готелі, клуби з } \\
\text { проживанням, готелі у пристосованих } \\
\text { транспортних засобах тощо) }\end{array}$} & & $\begin{array}{l}\text { Кафе (кав'ярня, чайний } \\
\text { салон, інтернет-кафе, інші } \\
\text { види кафе) }\end{array}$ \\
\hline & & & Кафетерій \\
\hline & & & Закусочна, шинок \\
\hline & & & Їдальня \\
\hline & \multirow{3}{*}{$\begin{array}{l}\text { Аналогічні засоби розміщення, } \\
\text { зокрема пансіонати, будинки відпочинку, } \\
\text { туристичні бази }\end{array}$} & & Пивна зала \\
\hline & & & Паб \\
\hline & & & Буфет \\
\hline \multirow{3}{*}{ 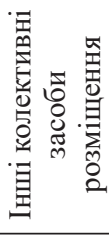 } & $\begin{array}{l}\text { Помешкання, призначені для відпочинку } \\
\text { (комплекси будинків, організовані як житло, } \\
\text { або бунгало) }\end{array}$ & \multirow{4}{*}{ 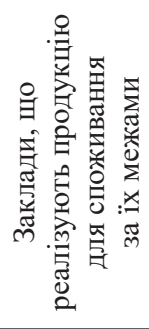 } & Фабрика-заготівельня \\
\hline & Майданчики для кемпінгу & & Фабрика-кухня \\
\hline & Інші колективні засоби розміщення & & Домова-кухня \\
\hline \multirow{4}{*}{ 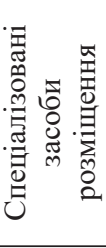 } & Оздоровчі засоби розміщення & & $\begin{array}{l}\text { Ресторан за спеціальним } \\
\text { замовленням }\end{array}$ \\
\hline & Табори праці та відпочинку & \multirow{4}{*}{ 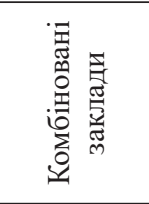 } & Ресторан-бар \\
\hline & Громадські транспортні засоби & & Кафе-бар \\
\hline & Конгрес-центри & & Кафе-пекарня \\
\hline \multirow{6}{*}{ 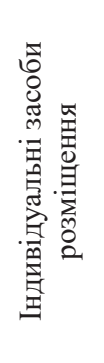 } & Орендовані засоби розміщення & & Нічний клуб \\
\hline & Кімнати, орендовані в сімейних будинках & & \\
\hline & $\begin{array}{l}\text { Житло, орендоване у приватних осіб або } \\
\text { через агентства }\end{array}$ & & \\
\hline & Неосновне власне житло & & \\
\hline & $\begin{array}{l}\text { Житло, яке надають безкоштовно родичам } \\
\text { та знайомим }\end{array}$ & & \\
\hline & Інші індивідуальні засоби розміщення & & \\
\hline
\end{tabular}

Із загальної чисельності колективних засобів розміщення кількість готелів та аналогічних засобів розміщування складала 3165 суб'єктів господарювання, інших аналогічних засобів розміщування - 2 170. Також варто відзначити структуру закладів розміщення за організаційно-правовою формою. Так, із загальної чисельності колективних засобів розміщення 1626 суб'єктів господарювання - це юридичні особи, 3709 - фізичні особи-підприємці, тобто 70\% від загальної кількості закладів розміщення - це малий і середній бізнес, здебільшого готельний бізнес для зазначених фізичних осіб-підприємців є основним видом діяльності.

Щодо закладів ресторанного господарства, то, відповідно до даних Державного комітету статистики України, їх кількість становила 64354 суб'єктів господарювання, із них 5714 юридичних осіб, 58640 фізичних осіб-підприємців (90\% від загальної структури). 
Якщо порівнювати загальну ситуацію у світі, то кількість міжнародних туристичних прибуттів у 2019 році досягла близько 1,5 мільярда, що на 4\%, або на 54 мільйони, перевищує показники 2018 року. Так, за даними UNWTO, 2019 рік став для світового туризму вже десятим поспіль роком з позитивною динамікою. Так, у 2019 році в усіх регіонах спостерігалося зростання кількості міжнародних прибуттів. Однак невизначеність навколо Brexit, банкрутство найбільшої туристичної компанії Thomas Cook, геополітична й соціальна напруженість, глобальний економічний спад сприяли сповільненню зростання у 2019 році, яке можна порівняти з винятковими темпами 2017 i 2018 років. Це сповільнення торкнулося переважно країн з розвиненою економікою, зокрема Європи і Азіатсько-Тихоокеанського регіону [1].

Однак, незважаючи на позитивні прогнози щодо туристичного сезону, у 2020 році сфера гостинності України першою відчула на собі наслідки активної фази карантину. Так, більшість готелів до середини травня залишались зачиненими і не мали можливості офіційно приймати відвідувачів. Також обмеження торкнулися масових заходів, зокрема фестивалів, концертів, спортивних змагань, які зазвичай приваблюють гостей 3 різних міст та країн.

Загалом втрати туристичної галузі в Україні оцінюються у понад 1,5 млрд. дол. США. Пізній початок курортно-рекреаційного сезону внаслідок впровадження обмежувальних заходів також створив кумулятивний ефект, який негативно вплинув як на індустрію відпочинку та подорожей, так і на супутні галузі, такі як готельно-ресторанний бізнес, транспорт (пасажирські перевезення), роздрібна торгівля, індустрія розваг та діяльність установ культури. Додатково до поточних та прогнозованих втрат сфера туризму Українських Карпат цього року вже постраждала від низького попиту на гірськолижний відпочинок внаслідок аномально теплої зими. Із введенням адаптивної фази карантину, початком «високого сезону» справи в готельєрів покращились. Більш того, обмеження пересування (закриті кордони) сприяють розвитку внутрішнього туризму, адже зростає попит на відпочинок в Україні [1].

Останні результати досліджень надають всі підстави вважати, що економічне зростання діяльності підприємств готельно-ресторанного господарства в Україні стримується багатьма причинами, серед яких слід назвати такі: економічна криза, воєнний конфлікт на сході країни, недосконала нормативно-правова система, невідповідність сучасним міжнародним стандартам. Недоліком також є відсутність чітких стратегій управління готельно-ресторанним господарством як у внутрішньому, так i у зовнішньому середовищах. Крім цього, можна зазначити, що відсутні необхідна інфраструктура, належна якість товарів і послуг, що відображається на рівні якості обслуговування споживачів, відсутності чіткого контролю, недостатній популяризації вітчизняного українського туристичного продукту [2].

Використовуючи потенціал готельно-ресторанного господарства та здійснюючи ефективне керування ним, можемо оптимізувати політику управління й стабілізацію платіжного балансу в країні. Розвиток готельно-ресторанного господарства суттєво впливає на зайнятість населення, його мобільність. Кількість робочих місць у туристичній індустрії зростає в 1,5 рази швидше, ніж у будь-якому іншому секторі економіки [6].

Важливою є роль готельно-ресторанного господарства щодо виконання соціальної функції, яка акцентує увагу на двох аспектах. По-перше, розвиток готельно-ресторанного господарства вирішує проблему безробіття, підвищуючи рівень життя працівників цієї галузі, по-друге, він сприяє задоволенню індивідуальних і колективних потреб (нові враження, зміна місця перебування, надання економічних благ і послуг відповідно до вимог і бажань споживачів). Велике значення має відтворення потенціалу людських ресурсів, тому загалом соціальний ефект від готельно-ресторанного господарства дуже масштабний [8]. 
Варто відзначити економічну функцію, завдяки якій туризм виділився в окрему сферу господарства, що приносить високі прибутки, активно сприяс економічному та соціальному розвитку суспільства, підвищенню якості життя його членів.

Незважаючи на те, що галузь готельно-ресторанного господарства все ж таки починає поступово відновлюватися, все ще існують ризики занепаду, тому що друга хвиля захворювання вирує майже в усіх країнах, а нові обмежувальні заходи все частіше впроваджуються.

У готельно-ресторанному господарстві України можна відзначити такі позитивні тенденції:

1) поглиблення спеціалізації підприємств готельно-ресторанного господарства;

2) утворення міжнародних ланцюгів та кластерів у галузі готельно-ресторанного господарства;

3) розвиток мережі малих та середніх підприємств готельно-ресторанного господарства;

4) впровадження сучасних комп’ютерних технологій та інноваційних процесів [2].

Взірцем для переймання позитивного досвіду управління розвитком готельно-ресторанного господарства, безумовно, є західні готелі та ресторани зі злагодженою структурою внутрішньої та зовнішньої організації роботи [3].

Для покращення показників розвитку готельно-ресторанного господарства та його позитивного впливу на соціально-економічний розвиток країни необхідні створення відповідної нормативно-правової бази, створення ефективної стратегії розвитку, пошук кращих управлінських рішень, удосконалення управління якістю товарів та послуг тощо [4].

Висновки. Належний рівень розвитку готельно-ресторанного господарства сприяє пожвавленню всіх соціально-економічних контактів та зв'язків, посилює економічний потенціал країни, піднімає рівень соціального розвитку суспільства. Дослідження дає можливість стверджувати, що існує достатня кількість перспектив розвитку підприємств готельно-ресторанного господарства України та їх позитивного впливу на соціально-економічний розвиток країни, незважаючи на умови нестабільної ситуації, в якій опинилась національна економіка країни. Також цілком очевидним є те, що існує необхідність вжиття радикальних і дієвих заходів та нормативно-правових актів у контексті управління готельно-ресторанним господарством. Необхідно вжити першочергових заходів задля відновлення функціонування та розвитку підприємств готельно-ресторанного господарства, які зазнали економічного удару від Covid-19, яких потребує галузь. Підприємства готельно-ресторанного господарства нині очікують вжиття таких цільових заходів від держави:

- заборона нарахування штрафів та пені або інших фінансових санкцій на період карантину та 12 місяців після;

- заборона на нараховування відсотків та інших платежів за користування кредитними коштами;

- відтермінування сплати коштів банкам/фінансовим установам;

- зниження ПДВ для підприємств готельно-ресторанного господарства до 10\%;

- впровадження «податкових канікул»;

- зниження податку на землю;

- доступні кредитні лінії;

- створення безвідсоткових лояльних програм.

Такі заходи суттєво допоможуть прискорити процес відновлення бізнесу після негативного впливу кризи, не втратити й зберегти бізнес, який уже найближчим часом знову запрацює та буде наповнювати бюджет країни. Спалах Covid-19 став приголомшливим ударом для світового та українського туризму, але якщо звернути увагу на можливі шляхи вирішення цієї ситуації, то можна побачити, що невдовзі готельно-ресторанне господарство зможе відновити свою діяльність. 


\section{Список використаних джерел:}

1. Travel \& Tourism Economic Impact 2019/ World Travel \& Tourism Council. URL: www.wttc.org/ research/economicimpactanalysis/countryreports (дата звернення: 20.10.2020).

2. Войнаренко С.М. Комунікативна політика підприємств у сучасних умовах. Вісник Хмельницького національного університету. 2011. № 6. Т. 2. С. 51-54.

3. Данько Н.I. Управління якістю готельних підприємств в Україні. Проблеми економіки. 2011. № 1. С. 67-72.

4. Коваленко Л.О., Ремньова Л.М. Фінансовий менеджмент : навчальний посібник. Київ : Знання, 2008. 483 c.

5. Максимюк С.О. Організаційний механізм економічної безпеки на прикладі підприємств індустрії гостинності. Актуальні проблеми економіки і торгівлі в сучасних умовах євроінтеграuзiі : матеріали наукової конференції. Львів : ЛТЕУ, 2017. С. 428-430.

6. Миронова М.І., Миронов Ю.Б. Показники ефективності діяльності підприємств індустрії гостинності. Сучасні технології менеджменту, інформачійне, фінансове та облікове забезпечення розвитку економіки в умовах євроінтегращії : матеріали Всеукраїнської науково-практичної конференції. Черкаси : Східноєвропейський університет економіки і менеджменту, 2020. C. $517-520$.

7. Валінкевич Н.В., Орлова К.Є. Удосконалення економічного механізму оцінки стану розвитку туризму в регіоні. Економіка. Управління. Інноващії. 2010. № 1. С. 63-68. URL: http://nbuv.gov.ua/UJRN/eui_2010_1_4 (дата звернення: 20.10.2020).

8. Федорченко В.К. Уніфіковані технології готельних послуг. Київ : Вища школа, 2001. $237 \mathrm{c}$.

\section{References:}

1. Travel \& Tourism Economic Impact 2019 / World Travel \& Tourism Council. Available at: www.wttc.org (accessed 20 October 2020).

2. Voinarenko S.M. (2011) Komunikatyvna polityka pidpryiemstv u suchasnykh umovakh [Communicative enterprise policy in modern conditions]. Visnyk Khmelnytskoho natsionalnoho universytetu, no. 6, vol. 2, pp. 51-54.

3. Danko N.I. (2011) Upravlinnia yakistiu hotelnykh pidpryiemstv v Ukraini [Quality Management of Hotel Enterprises in Ukraine]. Problemy ekonomiky, no. 1, pp. 67-72.

4. Kovalenko L.O., Remnova L.M. (2008) Finansovyi menedzhment [Financial management]. Kyiv: Znannia. (in Ukrainian)

5. Maksimyuk S.O. (2017) Organizacijnij mekhanizm ekonomichnoi bezpeki na prikladi pidpriemstv industrii gostinnosti [Organizational mechanism of economic security on the example of enterprises of the hospitality industry]. Lviv: LTEU, pp. 428-430.

6. Mironova M.I., Mironov Y.B. (2020) Pokazniki efektivnosti diyal'nosti pidpricmstv industrii gostinnosti [Indicators of efficiency of enterprises of the hospitality industry]. Cherkasy: Eastern European University of Economics and Management, pp. 517-520.

7. Valinkevych N.V., Orlova K.E. (2010) Udoskonalennia ekonomichnoho mekhanizmu otsinky stanu rozvytku turyzmu $\mathrm{v}$ rehioni [Improving the economic mechanism for assessing the state of tourism development in the region]. Ekonomika. Upravlinnya. Innovacziyi [Economy. Management. Innovation] (electronic journal), no. 1, pp.63-68. Available at: http://nbuv.gov.ua/UJRN/eui_2010_1_4 (accessed 20 October 2020).

8. Fedorchenko V.K. (2001) Unifikovani tekhnolohii hotelnykh posluh [Unified technologies for hotel services] (Ukraine, Kiev, 2001). Kyiv: Vyshcha shkola. (in Ukrainian) 